\title{
Manajemen Blended Learning Berbasis Whatsapp pada Masa Pandemi Covid-19 (Studi Kasus Di SMAN 1 Manggelewa)
}

\author{
Muh. Elyas Prabowo ${ }^{1}$, Muslimin ${ }^{2}$ \\ ${ }^{1,2}$ UIN Sunan Gunung Djati Bandung \\ muhelyasprabowo@gmail
}

\begin{abstract}
Indonesian education is improving itself according to all the limitations that occurred during the Covid-19 Pandemic. Blended Learning is one of the solutions for implementing learning in the midst of a pandemic. SMAN 1 Manggelewa is one of the schools that applies Blended Learning in learning during a pandemic. This study aims to determine the policy of the West Nusa Tenggara Provincial Government on high school level learning, know the WhatsApp-based Blended Learning management model at SMAN 1 Manggelewa, know the advantages and disadvantages of the WhatsApp-based Blended Learning model at SMAN 1 Manggelewa and find out how the Blended Learning model is effective for high school level in the future. The research used a descriptive qualitative approach. Primary data were obtained from SMAN 1 Manggelewa, while secondary data were obtained from the appropriate literature. The results showed that the West Nusa Tenggara Provincial Government continued the central government regulation, namely limiting face-to-face learning. SMAN 1 Manggelewa has implemented WhatsApp-based Blended Learning through groups managed by subject teachers. The implementation of Blended Learning at SMAN 1 Manggelewa went well despite several obstacles. For future projections, Blebded Learning can be further collaborated with technology in the form of an LMS (Learning Management System) through Moodle.
\end{abstract}

Keyword: models, management, blended learning, covid-19

\begin{abstract}
ABSTRAK
Pendidikan Indonesia berbenah diri menyesuaikan dengan segala keterbatasan yang terjadi pada masa Pandemi Covid-19. Blended Learning menjadi salah satu solusi untuk melaksanakan pembelajaran di tengah pandemi. SMAN 1 Manggelewa adalah salah satu sekolah yang menerapkan Blended Learning dalam pembelajaran pada masa pandemi. Penelitian ini bertujuan untuk mengetahui kebijakan Pemerintah Provinsi Nusa Tenggara Barat pada pembelajaran jenjang SMA, mengetahui model manajemen Blended Learning Berbasis WhatsApp di SMAN 1 Manggelewa, mengetahui keunggulan dan kelemahan model Blended Learning Berbasis WhatsApp di SMAN 1 Manggelewa dan mengetahui bagaimanakah model Blended Learning yang efektif untuk jenjang SMA pada masa yang akan datang. Penelitian menggunakan pendekatan kualitatif deskriptif. Data primer diperoleh dari SMAN 1 Manggelewa sedangkan data sekunder diperoleh dari literatur yang sesuai. Hasil penelitian menunjukkan bahwa Pemerintah Provinsi Nusa Tenggara Barat melanjutkan regulasi pemerintah pusat yaitu membatasi pembelajaran tatap muka. SMAN 1 Manggelewa telah menerapkan Blended Learning berbasis WhatsApp melalui grup yang dikelola oleh guru mata pelajaran. Pelaksanaan Blended Learning di SMAN 1 Manggelewa berjalan dengan baik meski ditemukan beberapa kendala. Proyeksi ke depan, Blebded Learning bisa lebih dikolaborasikan dengan teknologi dalam bentuk LMS (Learning Management System) melalui Moodle.
\end{abstract}

Kata kunci: model, manajemen, blended learning,covid-19 


\section{PENDAHULUAN}

Pandemi Covid-19 memberikan dampak yang sangat sistemik pada seluruh aspek kehidupan. Dalam konteks negara Indonesia, adanya Keputusan Presiden Nomor 11 Tahun 2020 tanggal 23 Maret 2020 tentang Penetapan Kedaruratan Kesehatan Masyarakat Corona Virus Disease (Covid-19) merupakan awal penerapan kebijakan khusus di seluruh sektor termasuk dunia pendidikan.

Situasi Pandemi Covid-19 menjadi tantangan besar dalam dunia pendidikan di Indonesia. Pada awal adanya kasus Covid-19 sekolah diliburkan selama 14 hari, ternyata kebijakan ini dinilai tidak efektif. Seiring dengan semakin merebaknya kasus Covid-19 terjadi perubahan kebijakan yaitu belajar dari rumah sampai batas waktu yang belum bisa ditentukan. Kebijakan ini diambil untuk menghindari munculnya klaster baru penyebaran Covid-19.

Kondisi pandemi Covid-19 mengakibatkan perubahan proses pembelajaran pada seluruh jenjang pendidikan, dari pendidikan anak usia dini hingga pada perguruan tinggi. Keputusan Bersama Menteri Pendidikan dan Kebudayaan, Menteri Agama, Menteri Kesehatan dan Menteri Dalam Negeri Republik Indonesia Tentang Panduan Penyelenggaraan Pembelajaran Pada Tahun Ajaran 2020/2021 dan Tahun Akademik 2020/2021 di Masa Pandemi Corona Virus Disease (Covid-19) mejadi acuan dan pedoman bagi seluruh Dinas Pendidikan di Indonesia. Dalam pelaksanaan regulasi ini diperkuat dengan penerbitan regulasi di tingkat Pemerintah Daerah. Blended Learning berpeluang besar menjadi salah satu solusi dalam melaksanakan pembelajaran dalam situasi pandemi seperti saat ini.

Hasil survey APJII (Asosiasi Penyelenggara Jasa Internet Indonesia) menunjukkan bahwa pengguna internet di Indonesia pada tahun 2019-2020 Q2 sebesar 196,71 juta jiwa atau $73 \%$ dari total populasi sebesar 266,91 juta jiwa. Data ini mengalami peningkatan dibandingkan hasil survey APJII pada tahun 2018 dimana pengguna internet sebesar 171.11 juta jiwa (APJII, 2020). Watie (2011) menjelaskan bahwa muncul dan berkembangnya internet membawa cara komunikasi baru di masyarakat. Media sosial hadir dan merubah paradigma berkomunikasi di masyarakat saat ini. Komunikasi tak terbatas jarak, waktu, dan ruang. Bisa terjadi di mana saja, tanpa harus tatap muka. Bahkan media sosial mampu meniadakan status sosial, yang sering kali sebagai penghambat komunikasi.

Media sosial sudah menjadi bagian hidup dari masyarakat di dunia, khususnya di Indonesia. Penggunaan media sosial makin hari makin meningkat karena perkembangan dan inovasi digital saat ini. Media sosial menjadi salah satu kebutuhan pokok digital masyarakat di Indonesia. Media sosial terdiri dari WhatApp, Instagram, Facebook, Line, dan sebagainya. 
Pengguna internet di Indonesia sangat banyak, dan berdampak pada penggunaan sosial media.

Kehadiran dan kemajuan media sosial khususnya WhatsApp sebagai sistem komunikasi yang canggih di masa ini, sehingga tenaga pendidik juga dituntut mampu beradaptasi dengan perkembangan dan kemajuan teknologi informasi dan komunikasi, dengan cara mengembangkan sendiri atau memanfaatkan teknologi yang sudah ada, seperti WhatsApp sebagai alat untuk mentransfer pengetahuan dengan cepat tanpa harus terpaku pada waktu pembelajaran tertentu saja, dengan tetap memperhatikan berbagai faktor agar tujuan pembelajaran dapat tercapai (I Made Pustikayasa, 2019).

SMAN 1 Manggelewa merupakan salah satu sekolah peserta simulasi tatap muka sesuai keputusan Dinas Pendidikan Provinsi Nusa Tenggara Barat pada bulan September tahun 2019. Berdasarkan hasil observasi di SMAN 1 Manggelewa ditemukan bahwa Dalam pelaksanaan pembelajaran pada pada masa pandemi, sekolah ini telah menerapkan Blended Learning. Secara spesifik pembelajaran dilaksanan secara daring dan luring dengan memperhatikan protokol kesehatan yang ketat. Proses pembelajaran disampaikan secara verbal namun dan juga diwujudkan dalam bentuk virtual.

Berdasarkan uraian di atas maka peneliti melakukan penelitian tentang "Manajemen Blended Learning Berbasis WhatsApp Pada Masa Pandemi Covid-19 dengan studi kasus di SMAN 1 Manggelewa. Tujuan dari penelitian ini adalah untuk mengetahui kebijakan pembelajaran jenjang SMA pada masa Pandemi Covid-19 di Provinsi Nusa Tenggara Barat, mengetahui model manajemen Blended Learning Berbasis WhatsApp di SMAN 1 Manggelewa, mengetahui keunggulan dan kelemahan model Blended Learning Berbasis WhatsApp di SMAN 1 Manggelewa dan mengetahui bagaimanakah model Blended Learning yang efektif untuk jenjang SMA pada masa yang akan datang.

\section{METODE}

Penelitian ini menggunakan metode kualitatif deskriptif. Menurut Sugiono, penelitian kualitatif adalah penelitian dimana peneliti ditempatkan sebagai instrumen kunci, teknik pengumpulan data dilakukan secara penggabungan dan analisis data bersifat induktif (Sugiono, 2010). Adapun tujuan dari penelitian ini adalah untuk mengungkapkan kejadian atau fakta, keadaan, fenomena, variabel dan keadaan yang terjadi saat penelitian berlangsung dengan menyuguhkan apa yang sebenarnya terjadi. Penelitian ini menafsirkan dan menguraikan data yang bersangkutan dengan situasi yang sedang terjadi, sikap serta 
pandangan yang terjadi di dalam suatu masyarakat, pertentangan antara dua keadaan atau lebih, hubungan antar variable yang timbul, perbedaan antar fakta yang ada serta pengaruhnya terhadap suatu kondisi, dan sebagainya. Data dalam penelitian ini diperoleh dari dua sumber yaitu data primer dan data sekunder. Data primer diperoleh dari SMAN 1 Manggelewa sedangkan data sekunder diperoleh dari literatur yang sesuai dengan penelitian ini. Adapun teknik pengumpulan data pada penelitian ini dilakukan dalam bentuk observasi, wawandara dan dokumentasi. Data dari peneltian ini selanjutnya dianalisis dengan pendekatan model Miles and Huberman yang terdiri dari tiga langkah, yaitu reduksi data (data reduction), displai data (data display), dan kesimpulan dan verifikasi (conclusion drawing/verification).

\section{HASIL PEMBAHASAN}

Kebijakan Pembelajaran Jenjang Sma Pada Masa Pandemi Covid-19 di Provinsi Nusa Tenggara Barat

Sejalan dengan kebijakan pemerintah pusat, pemerintah daerah provinsi Nusa Tenggara Barat juga mengambil langkah yang sama degan terbitnya Surat Edaran Gubernur Nomor 420/3320.UM/DIKBUD tentang Penyelenggaraan Pembelajaran di Satuan Pendidikan pada Tahun Pelajaran 2020/2021 di Masa Pandemi Corona Virus Disease 19 (Covid-19). Isi dari surat edaran tersebut adalah larangan terhadap pelaksanaan pembelajaran secara tatap muka. Pembelajaran dilaksanakan dengan belajar dari rumah melalui sistem daring/online/luring/modul dan atau bentuk lain dengan memanfaatkan segala sumber daya yang dimiliki secara optimal.

Pada akhir tahun 2020 jajaran Dinas Pendidikan Provinsi Nusa Tenggara Barat menyelenggarakan simulasi pembelajaran tatap muka dengan penerapan protokol kesehatan yang ketat. Dalam pelaksanaan simulasi ini berpedoman pada Panduan Penyelenggaraan Pembelajaran di masa pandemi Covid-19 yang dikeluarkan oleh Kementerian Pendidikan dan Kebudayaan. Bagi sekolah yang menyelenggarakan pembelajaran tatap muka harus memenuhi beberapa syarat diantaranya tersedia toilet bersih dan layak, tersedia fasilitas kesehatan, wajib memakai masker, tersedia sarana cuci tangan atau hand sanitizer dan disinfektan, menyediakan thermogun (alat pengukur suhu tubuh), pemetaan satuan pendidikan untuk mengetahui siapa yang punya komorbid (penyakit penyerta), persetujuan komite sekolah dan orang tua/wali siswa. Lebih lanjut Dinas Pendidikan Provinsi Nusa 
Tenggara Barat meneribikan surat edaran Nomor 441/1880.UM/Dikbud tentang Kewajiban Penggunaan Masker Dalam Rangka Pencegahan Penyebaran Covid-19.

Regulasi terakhir terkait dengan pembelajaran di lingkup Dinas Pendidikan Provinsi

Nusa Tenggara Barat adalah surat edaran lanjutan Nomor 420/2120.UM/Dikbud tentang Perpanjangan Masa Pendampingan dan pengawasan siswa/siswi belajar mandiri di Rumah. Poin penting dari surat edaran tersebut adalah:

1. Ditegaskan bahwa layanan kegiatan belajar mandiri di rumah diperpanjang kembali;

2. Agar Kepala Sekolah memastikan para Guru memberikan layanan belajar mandiri dirumah dengan tidak memberikan layanan yang berbentuk tugas secara kelompok melainkan dengan memanfaatkan teknologi informasi dan komunikasi secara efektif dan efisien (tetap di dalam rumah) atau bentuk layanan belajar mandiri lainnya;

3. Agar kepala sekolah mengefektifkan kunjungan rumah (home visit) untuk memberikan layanan belajar secara konvensional di rumah bagi siswa yang tidak bisa belajar daring (online) atau semi online, dengan menugaskan guru BP/BK atau guru yang relevan;

4. Sekolah dapat melakukan observasi tidak langsung atas aktivitas spiritual siswa selama bulan Ramadhan bekerjasama dengan orangtua/wali siswa. Hasil observasi tidak langsung dapat dipertimbangan menjadi bagian dari penilaian ranah apektif;

5. Agar Kepala Sekolah menyampaikan laporan progres belajar mandiri yang dilaksanakan oleh setiap Guru. Laporan disampaikan melalui Kepala Seksi Kurikulum SMA, Kepala Seksi Kurikulum SMA, dan Kepala Seksi Kurikulum PK PLK pada Dinas Dikbud Provinsi NTB;

6. Agar Kepala Sekolah menyampaikan progress hasil observasi tidak langsung atas aktivitas spiritual siswa selama bulan Ramadhan kepada Kepala Seksi siswabidang Pembinaan SMA, Bidang Pembinaan SMK, dan bidang PK PLK pada Dinas Dikbud Provinsi NTB;

7. Agar orangtua/wali memastikan putra/putrinya untuk tidak melakukan kegiatan di luar rumah seperti di pusat olahraga, tempat rekreasi, warung internet, pusat perbelanjaan, pusat permainan, mall, atau tempat berkumpul lainnya;

8. Agar orangtua/wali tidak mengijinkan putra/putrinya melakukan kegiatan yang diikutibanyak orang seperti: perlombaan/pertandingan, kegiatan seni budaya, pameran, nyongkolan dan lainnya;

9. Selama belajar mandiri di rumah agar para orangtua siswa mengawasi/ membimbing putra/putrinya; Apabila diperlukan diminta kepada orangtua /wali untuk berkomunikasi 
dengan para guru/wali kelas untuk menginformasikan perkembangan berlajar mandiri putra/putrinya di rumah.

Model Manajemen Blended Learning Berbasis WhatsApp di SMAN 1 Manggelewa pada masa pandemi Covid-19

Blended Learning merupakan salah satu metode pembelajaran yang telah lama berkembang. Namun pada awalnya kemunculannya, Blended Learning belum dikenal dengan baik. Karena pemahaman profesionalisme guru dalam pembelajaran masih terbatas pada bagaimana seorang guru memahami materi dan menyampaikannya. Kemudian kajian tentang Blended Learning berkembang dan menghasilkan pemahaman tentang manfaat, problematika serta kemungkinannya diterapkan dalam pembelajaran (Bahrul, 2019). Perkembangan Blended Learning sejalan dengan makin pesatnya perkembangan teknologi informasi dan komunikasi dalam bidang pendidikan, terutama komputer dan jaringan. Dewasa ini Blended Learning menjadi perhatian bagi insan pendidikan terkait dengan metode pembelajaran di tengah situasi Pandemi Covid-19.

Menurut Fitzpatrick, Jamey (2011) dalam (Sheren, dkk, 2018) Blended Learning merupakan kombinasi pembelajaran online dengan pembelajaran tatap muka (face to face) di kelas (konvensional). Sedangkan Garrison (2004) dalam (Sheren, dkk, 2018) menyatakan bahwa Blended Learning merupakan perpaduan yang efektif dengan berbagai model penyampaian, model pengajaran dan gaya pembelajaran yang dapat diimplementasikan dalam lingkungan belajar yang interaktif untuk seluruh mata pelajaran pada pembelajaran online (e-learning) dan tatap muka. Sedangkan Bambang (2019) mengemukakan bahwa dalam Blended Learning materi disajikan secara singkat, padat, dan sistematis, serta kaya akan sumber merangsang siswa untuk belajar dengan aktif.

Menurut Driscoll (2002) dalam Milya (2014), definisi Blended Learning merujuk pada empat konsep yang berbeda yaitu:

1. Blended Learning merupakan pembelajaran yang mengkombinasikan atau menggabungkan berbagai teknologi berbasis web, untuk mencapai tujuan pendidikan.

2. Blended Learning merupakan kombinasi dari berbagai pendekatan pembelajaran (seperti behaviorisme, konstruktivisme, kognitivisme) untuk menghasilkan suatu pencapaian pembelajaran yang optimal dengan atau tanpa teknologi pembelajaran. 
3. Blended learning juga merupakan kombinasi banyak format teknologi pembelajaran, seperti video tape, CD-ROM, web-based training, film) dengan pembelajaran tatap muka.

4. Blended Learning menggabungkan teknologi pembelajaran dengan perintah tugas kerja aktual untuk menciptakan pengaruh yang baik pada pembelajaran dan pekerjaan.

Meunurut Henzi (2004) dalam (Walid, 2018), konsep Blended Learning terdiri dari kombinasi berbagai bentuk alat pembelajaran misalnya kombinasi real time perangkat lunak, program pembelajaran berbasis web online dan aplikasi lainnya yang mendukung pada lingkungan belajar dan pengetahuan manajemen sistem. Pembelajaran Blended Learning perpaduan antara online, tatap muka dan mandiri yang dipandu oleh mentor, guru atau dosen dengan pembelajaran yang terstruktur berikut gambarannya:

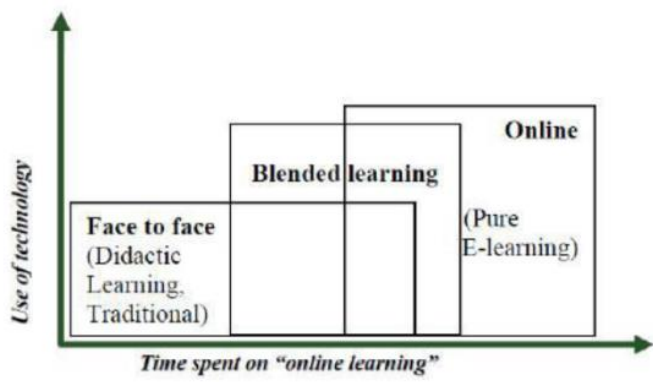

Sumber : Henzi and Procter (2004)

Gambar 1. Conception of Blended Learning

Dalam pembelajaran online learning, tentu harus dipakai sebuah perangkat lunak maupun perangkat keras yang digunakan untuk mendukung terselenggaranya online learning sebagai bagian dari Blended Learning. Salah satu bentuk perangkat lunak yang dapat digunakan adalah dengan aplikasi WhatsApp. Aplikasi ini merupakan salah satu bentuk perangkat lunak yang digunakan sebagai media sosial yang menghubungkan banyak orang dalam sebuah komunikasi audio visual dan juga didukung kemampuan chat yang relatif cepat bila dibandingkan aplikasi lainnya misalkan BBM, FB Masangger atau Yahoo Mesengger.

Agus Wilson (2020), menjelaskan bahwa pada masa Pandemi Covid-19 ini ada beberapa aplikasi yang sering digunakan dalam pembelajaran, yaitu:

\section{Whatsapp Group}

Sebagai media sosial chat, Whatsapp memudahkan penggunanya untuk saling berkomunikasi dan berinteraksi serta berdiskusi secara online dan tidak terlalu menghabiskan biaya terlalu banyak dalam pemakaiannya. Pengguna dapat berkomunikasi baik menggunakan tulisan, suara maupun video. 


\section{Google Classroom}

Aplikasi ini dikhususkan untuk media pembelajaran online, sehingga dapat memudahkan dosen dalam membuat, membagikan serta mengelompokkan setiap tugas tanpa menggunakan kertas lagi.

\section{Edmodo}

Sebuah platform pembelajaran sosial untuk guru/dosen dan siswa/mahasiswa yang menyediakan beberapa fitur untuk mendukung e-learning seperti penugasan, kuis, penilaian, dan lain sebagainya. Melalui Edmodo dosen dan peserta didik dapat berbagi catatan dan dokumen serta dapat melanjutkan diskusi secara online.

\section{Zoom}

Aplikasi ini menyediakan layanan konferensi jarak jauh dengan menggabungkan konferensi video, pertemuan online, obrolan, hingga kolaborasi seluler. Aplikasi ini banyak digunakan sebagai media komunikasi jarak jauh. Zoom memungkinkan pengguna melakukan meeting sampai 100 partisipan.

\section{Google Meet}

Secara default, Meet telah diaktifkan untuk $G$ Suite for Education. Aplikasi ini memungkinkan pengguna untuk melakukan panggilan video dengan 30 pengguna lainnya per pertemuan. Google Meet terintegrasi dengan G Suite, yang memungkinkan pengguna untuk dapat bergabung langsung dari Kalender atau undangan yang dikirim via email.

6. Webex

Aplikasi ini adalah teknologi kolaborasi yang dapat digunakan sebagai media tatap muka virtual antara dosen dan murid. Dosen akan mengajar seperti biasa melalui video, termasuk berbagi konten presentasi dan berinteraksi dengan papan tulis digital melalui layar komputer/smartphone.

\section{Loom}

Loom adalah aplikasi screen recorder atau aplikasi untuk merekam segala aktifitas yang kita lakukan di layar komputer atau laptop dan dapat diupload langsung ke sebuah link. Hasil videonya pun dapat diunduh ataupun disebarluaskan via email dan media sosial. Loom sangat mempermudah penggunanya yang ingin mempresentasikan bisnis mereka atau saat ketika mempresentasikan pekerjaan mereka ketika meeting.

8. Quizizz

Merupakan sebuah web tool untuk membuat permainan kuis interaktif yang digunakan dalam pembelajaran di kelas. Kuis interaktif yang dibuat memiliki hingga 4 (empat) 
pilihan jawaban termasuk jawaban yang benar dan dapat ditambahkan gambar ke latar belakang pertanyaan.

\section{Duolingo}

Aplikasi belajar bahasa gratis yang diciptakan oleh Luis von Ahn dan Severin Hacker.

Aplikasi ini selain tersedia dalam versi web juga tersedia dalam versi Android, iOS dan Windows Phone.

Untuk SMAN 1 Manggeewa aplikasi yang digunakan dalam pelaksanaan Blended Learning adalah aplikasi WhatsApp. Dengan pertimbangan aplikasi ini sudah lazim dan banyak digunakan oleh guru maupun siswa. WhatsApp merupakan sebuah aplikasi yang dapat digunakan untuk pengguna iPhone, BlackBerry, Android, serta Symbian (Nokia). Aplikasi WhatsApp hanya dapat bekerja untuk sesama pengguna yang memiliki aplikasi WhatsApp. Aplikasi WhatsApp ini dapat diunduh secara gratis di websitenya. Aplikasi ini menggunakan nomor telepon ponsel yang kita gunakan untuk berinteraksi dengan sesama pengguna WhatsApp. Aplikasi ini memungkinkan pengguna untuk dapat saling berkomunikasi satu sama lain. Aplikasi ini menggunakan fitur push sehingga Anda dapat selalu memberitahukan pesan yang sedang diterima.

WhatsApp ini mengandalkan koneksi internet melalui jaringan GPRS/EDGE/3G/4G atau Wi-Fi untuk menjalankannya. Aplikasi WhatsApp ini tidak keluar saat tidak tersambung dengan koneksi internet. pengguna dapat melihat kontak maupun perbincangan dengan teman walaupun tidak tersambung dengan koneksi internet, tetapi saat pengguna coba untuk mengirim pesan, terdapat tanda jam yang menandakan pesan Anda ditunda pengirimannya sampai terdapat koneksi internet.

WhatsApp secara resmi mengumumkan peluncuran fitur resmi bernama Whatsapp Web pada tanggal 22 Januari 2015. Fitur ini mencoba memfasilitasi penggunaan aplikasi ini untuk pengguna berbasis komputer. Laiknya WhatsApp berbasis telepon genggam, fitur ini membutuhkan koneksi internet sebagai jalur penyampaikan informasi. WhatsApp bekerja melalui portal online yang disediakan oleh pengembang yang beralamat di web.whatsapp.com. WhatsApp web pada prinsipnya berfungsi untuk membuka akun WhatsApp melalui perangkat komputer.

Fitur ini pada periode awal lebih mudah digunakan melalui aplikasi Chrome yang dikembangkan oleh Google. Sinkronisasi dibutuhkan untuk membuka akun WhatsApp melalui web ini. Pengembang menyediakan barcode yang perlu dipindai melalui aplikasi 
WhatsApp mobile. Pemindaian akan secara langsung membuka aplikasi Whatsapp sesuai dengan akun yang berfungsi pada telepon genggam yang digunakan untuk pemindaian.

Percakapan yang terdapat pada aplikasi WhatsApp di telepon seluler akan turut disajikan pada versi web ini. Sinkronisasi akan dilakukan secara otomatis apabila terjadi perubahan pada salah satu aplikasi yang aktif.

Beberapa fitur dasar yang ditawarkan aplikasi antara lain (I Made Pustikayasa, 2019):

1. Pesan

Pengguna dapat memanfaatkan koneksi internet untuk berkirim pesan kepada pengguna lain

\section{Chat Grup}

Pengguna dapat membuat grup yang terdiri dari nomor ponsel yang sudah terdaftar pada WhatsApp untuk memudahka berkomunikasi antar anggota dalam grup.

3. WhatsApp Web dan Desktop

Pengguna dapat mengirim dan menerima pesan WhatsApp langsung dari browser komputer atau langsung pada komputer dengan syarat WhatsApp pada phonsel tetap aktif.

4. Panggilan Suara dan Video WhatsApp

Pengguna dapat melakukan panggilan suara dan panggilan video (video call) di seluruh dunia menggunakan koneksi internet ponsel atau wi-fi.

5. Foto dan Video

Pengguna dapat berbagi foto dan video diantara pengguna baik personal maupun dalam grup.

\section{Enkripsi End to End}

Sistem keamanan untuk pengguna

Keunggulan aplikasi Whatsapp lainnya antara lain yaitu (Miksan, 2018):

1. Banyak digunakan terutama oleh kalangan mahasiswa (pengguna WhatsApp diseluruh dunia yaitu lebih dari 1 milyar orang)

2. Mudah diinstall dalam program smartphone (hanya butuh beberapa tahap dalam penginstalannya)

3. Data instalasi sangat ringan (Bila menggunakan playstore kurang lebih 18 Mega Bytes saja untuk mengunduh aplikasi WhatsApp)

4. Dapat dibuat grup untuk komunitas tertentu (user WhatsApp banyak yang membuat grup dengan latar belakang tertentu, misal grup alumni sekolah, grup rekan kerja, grup teman satu kelas dan lain sebagainya) 
5. Akselerasi chating yang relatif tinggi (banyak user menggunakan aplikasi WhatsApp karena kecepatannya dalam mengirim pesan)

6. Dapat digunakan untuk mengirim file, picture, pesan suara, video, GPS, kiriman web/link, emoji dan lain sebagainya Dalam teks WhatsApp juga dapat digunakan fitur huruf tebal (bold), huruf miring (italic) dan underline yang sangat bermanfaat misal untuk penegasan kata dan penegasan istilah tertentu.

7. Dapat mengetahui status penerima pesan, yaitu satu centang putih untuk tanda pesan pending, dua centang putih berarti pesan sudah diterima dan belum dibaca/dibuka, dan dua centang biru sebagai tanda pesan sudah diterima dan dibaca.

Pelaksanaan penggunaan grup WhatsApp sebagai media pembelajaran siswa SMAN 1 Manggelewa berjalan cukup baik dan terencana. Hal ini didukung dengan keberadaan smartphone yang sekarang bukan merupakan barang yang mahal saat ini. Hampir semua siswa dan guru saat ini memiliki smartphone, dan tidaklah terlalu sulit untuk mengoperasikannya. Pengaturan jadwal dalam pembelajaran ini dilakukan secara shift. Pengertian shift kerja sesuai Undang-Undang No.13 tahun 2003 tentang Ketenagakerjaan adalah pergeseran atau penetapan jam kerja (dari jam kerja pada umumnya) yang terjadi satu kali dalam 24 jam. Biasanya perusahaan menerapkan shift kerja dengan tujuan mengoptimalkan hasil kerja dan produktivitas. Misalnya untuk pembelajarna di SMAN 1 Manggelewa ditetapkan 2 shift dalam 24 jam yang masing-masing terdiri dari 2,5 jam kerja setiap shiftnya. Sebagai gambaran dapat dilihat pada gambar berikut ini:

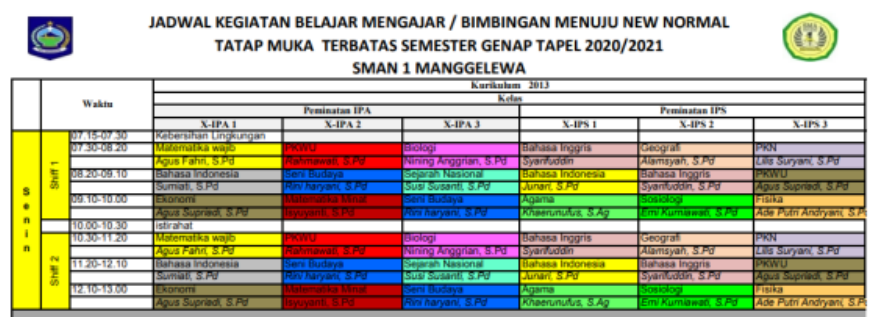

Sumber : SMAN 1 Manggelewa

Gambar 2. Jadwal shift Pembelajaran SMAN 1 Manggelewa

Blended Learning melalui media WhatsApp di SMAN 1 Manggelewa diawali dengan pembuatan grup untuk setiap mata pelajaran. Secara teknis aplikasi grup WhatsApp tersebut dijadikan sebagai media pembelajaran bagi guru dan siswa dengan cara para guru mengshare materi pembelajaran yang disampaikan melalui WhatsApp agar siswa mengakses dan melakukan pembelajaran di rumah. Group ini sebagai media untuk mengirim pesan ke anggota grup. Grup chat inilah yang digunakan untuk proses pembelajaran dalam kelas. Grup 
belajar hanya berisi satu kelas yang terlibat. Sehingga guru dapat selalu melakukan pembelajaran meski tanpa tatap muka karena situasi pandemi. Berikut adalah salah satu gambar tangkapan layar dari video embelajaran yang di share oleh guru di grup WhatsApp:

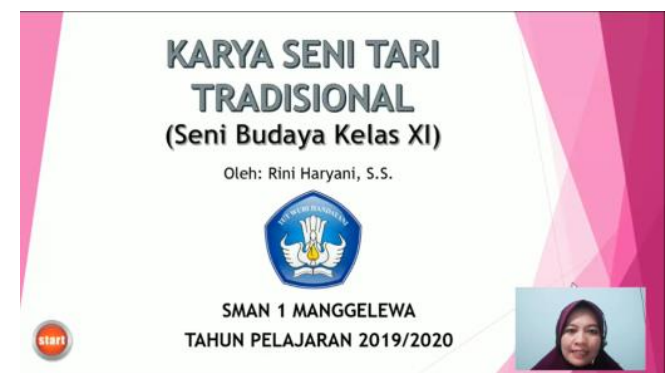

Sumber : SMAN 1 Manggelewa

\section{Gambar 3. Tampilan Video Pembelajaran SMAN 1 Manggelewa}

Proses pembelajaran di SMAN 1 Manggelewa tetap berlangsung dengan menerapkan Blended Learning. Materi pelajaran yang harus selesai dalam satu semester tetap bisa dijalankan meski pertemuan tatap muka sangat terbatas. Salah satu faktor pendukung adalah secara skill dan knowledge siswa dan guru sudah terbiasa menggunakan teknologi smartphone. Guru dan siswa membentuk grup, jika dibutuhkan siswa membentuk kelompok untuk kepentingan tugas maupun presentasi. Pada aplikasi WhatsApp terdapat tanda bintang pada yang dapat digunakan guru untuk menandai siswa yang kurang aktif dalam pembelajaran dan terdapat banyak emoticon yang dapat diberikan guru pada setiap siswa yang memberikan respon. Respon siswa dapat berupa pesan teks, voicenote/audio, gambar ataupun tulisan tangan yang difoto atau bahkan berupa dokumen. Langkah selanjutnya setelah dilakukan pembelajaran, ketika pembelajaran tatap muka di sekolah secara shift dilakukan penguatan materi atau dapat dilakukan assesment berupa tes tulis, tes lisan ataupun unjuk kerja sebagai tingkat ukuran kepahaman siswa terhadap materi. Hasil penilaian ini kemudian direkap oleh guru dan dilaporkan kepada Wakil Kepala Sekolah bidang kurikulum. Pada tahap ini komunikasi antara guru dan siswa menjadi sangat penting. Seperti diungkapkan oleh Fathu (2019), bahwa komunikasi baik antara guru dan peserta didik maupun peserta didik dengan peserta didik masih sangat penting untuk dilakukan. Mengingat bahwa dengan berkomunikasi akan lebih mudah diketahui sejauh mana pembelajaran tersebut berjalan dengan baik.

Penggunaan WhatsApp dalam Blended Learning di SMAN 1 Maggelewa dibagi menjadi dua tahap yaitu: tahap pelaksanaan yang dilakukan dengan cara mengidentifikasi, sosialisasi program, rapat koordinasi dan penetapan program yang meliputi: merumuskan program, 
menetapkan tujuan program, menyiapkan materi pembelajaran. Pelaksanaan lebih diperhatikan pada teknisnya meliputi: sarana dan prasarana, dan materi pembelajaran. Monitoring yang dilakukan untuk mengukur keberhasilan program yang dilaksanakan. Monitoring pada penggunaan WhatsApp sebagai media dalam Blended Learning dilakukan oleh Koordinator yang di tugaskan oleh kepala sekolah.

\section{Keunggulan dan Kelemahan Model Blended Learning di SMAN 1 Manggelewa pada masa pandemi Covid-19}

Pada dasarnya pembelajaran dengan pengembangan teknologi dengan kombinasi pembelajaran tatap muka maka dapat dihasilkan suatu pembelajaran yang lebih efektif dan efisien. Pembelajaran ini seimbang antara tatap muka dengan pembelajaran online yaitu dengan menggunakan multimedia yang dimuat dalam komputer, handphone, konfeksi video dan media tekonologi yang lainnya. Tenaga pengajar dengan siswa dapat melakukan komunikasi sekalipun dengan jarak dan tempat yang berbeda dan juga siswa dapat dilengkapi dengan pembelajaran tatap muka yang memungkingkan terdapat permasalahan dalam materi pembelajaran online.

Kelebihan Blended Learning adalah dapat melakukan menyesuaikan pembelajaran dengan karakteristik belajar siswa yang berbeda-beda. Misalnya, siswa yang enggan berdiskusi di kelas mungkin saja akan lebih aktif berdiskusi secara tertulis. Tidak semua orang berani dalam mengajukan pendapatnya apabila di tempat umum langsung seperti kelas. Ada saja siswa yang sebenarnya memiliki banyak ide namun kurang berani menunujukkannya. Dengan Blended Learning ini siswa yang lebih tertutup akan menjadi lebih aktif. Kelebihan lain dari Blended Learning adalah pembelajaran yang lebih efektif dan efisien, meningkatkan aksesbilitas, mempermudan dan mempercepat komunikasi.

Proses pembelajaran dengan Blended Learning berbasis WhatsApp di SMAN 1 Manggelewa secara umum berjalan baik dan lancar. Salah satu faktor pendukung adalah hampir seluruh guru dan siswa telah memiliki, memahami dan terampil dalam mengoperasikan smartphone. Disamping itu keaktifan guru dalam memberikan materi pembelajaran melalui WhatsApp juga menjadi kunci suksesnya pembelajaran di tengah Pandemi Covid-19 ini. Beberapa pengalaman menarik dari guru dalam pembelajaran ini adalah tersedianya banyak waktu untuk mengeksplore pembelajaran. Siswa mempunyai peluang untuk lebih memahami materi pembelajaran dengan mencari materi melalui internet dan sumber lain. Dengan demikian ketika pertemuan tatap muka di sekolah tejadi silang 
pengetahuan antar siswa yang sangat beragam, kemudian guru memberikan konfirmasi dan penguatan.

Dari sisi proses pembelajaran, dengan Blended Learning guru dapat meminta kepada peserta didik untuk mengkaji materi pelajaran sebelum pembelajaran tatap muka berlangsung dengan menyiapkan tugas-tugas pendukung. Target pencapaian materi-materi ajar dapat dicapai sesuai dengan target yang ditetapkan. Guru dapat mengelola dan mengontrol pembelajaran yang dilakukan siswa diluar jam pelajaran siswa. Keunggulan lainnya adalah diskusi dapat berlangsung secara online/offline dan dapat dilaksanakan diluar jam pelajaran, kegiatan diskusi berlangsung baik antara peserta didik dengan guru maupun antara antar siswa itu sendiri.

Kendala yang muncul dalam penerapan Blended Learning sangat beragam. Menurut Noer dalam Husamah (2014), bahwa pembelajaran online mempunyai kendala interaksi langsung antara siswa dengan pengajar bagaimanapun pengajar perlu feedback dari siswa dan siswa juga butuh feedback dari pengajar. Alasan mengapa pembelajaran online kurang memuaskan padahal materi sudah tersedia bisa belajara dimana saja karna siswa juga butuh interaksi dan interaksi langsung dengan pengajar. Sekalipun sekarang pembelajaran online juga dilengkapi dengan pengembangan video conference dan webchat siswa dengan siswa, siswa dengan guru butuh interaksi langsung satu sama lain.

Blended Learning sulit diterapkan apabila sarana dan prasarana tidak mendukung, tidak meratanya fasilitas yang dimiliki siswa seperti komputer dan akses internet, kurangnya pengetahuan masyarakat terhadap penggunaan teknologi, pengajar perlu memiliki keterampilan dalam menyelenggarakan e-learning, pengajar perlu menyiapkan waktu untuk mengembangkan dan mengelola pembelajaran sistem e-learning seperti mengembangkan materi dan menyiapkan assesment, pengajar perlu menyiapkan referensi digital sebagai acuan siswa dan referensi digital yang terintegrasi dengan pembelajaran tatap muka Diperlukan strategi pembelajaran oleh pengajar untuk memaksimalkan potensi blended learning.

Dalam penerapan Blended Learning di SMAN 1 Manggelewa ditemukan beberapa kendala utama sebagai berikut:

1. Kurangnya Sarana dan Prasarana.

Tidak meratanya pengetahuan guru tentang Blended Learning. Karena memang pola ini baru diketahui oleh guru sejak merebaknya Pandemi Covid-19, sehingga pada awalnya dirasa cukup menyulitkan guru karena guru yang belum terbiasa melaksanakan pendidikan jarak jauh. Kekhawatiran guru tentang siswa yang akan merasa sulit 
memahami materi pembelajaran dan kurangnya minat siswa untuk mengikuti pendidikan jarak jauh.

2. Fasilitas yang Dimiliki Siswa Berbeda

Fakta yang terjadi di lapangan ternyata tidak semua siswa memiliki smartphone. Ada beberapa siswa yang smartphone-nya masih meminjam kepada orang tua. Sehingga pada saat orang tua siswa hendak berangkat kerja atau tidak sedang berada di rumah maka smartphone tersebut akan dibawa dan dengan terpaksa siswa seringkali harus meminta izin kepada guru untuk tidak mengikuti pembelajaran. Belum lagi perihal ketersediaan kuota internet dan jangkauan sinyal internet disetiap siswa dan guru berbeda, menjadi penyebab Blended Learning tidak dapat berjalan lancar, namun demikian dapat disiasati dengan memanfaatkan video pembelajaran yang dikirimkan guru.

3. Kurangnya Kerja sama Orang tua siswa

Keberhasilan Blended Learning ini sangat dipengaruhi oleh kerja sama yang dilakukan orang tua siswa. Sedangkan kenyataannya tidak jarang pada saat dilaksanakannya pembelajaran ada beberapa siswa yang meminta izin meninggalkan pembelajaran dikarenakan harus membantu orang tuanya. Ataupun ada beberapa orang tua yang dirasa kurang membantu memantau aktivitas siswa pada saat pembelajaran berlangsung ataupun memantau siswa dalam menyelesaikan tugas-tugasnya disekolah.

\section{Model Blended Learning Yang Efektif Untuk Jenjang SMA ada masa Yang Akan Datang.}

Dengan krisis kesehatan global yang terjadi tentu adalah hal yang sangat wajar untuk berfokus pada kondisi yang terjadi saat ini, tetapi ketika dunia mulai merasakan efek menguntungkan dari tindakan darurat terhadap Covid-19, sekarang saatnya untuk melihat ke masa depan. Situasi masa depan tentu akan sangat berbeda dengan situasi saat ini. Seperti saat ini pemerintah mengeluarkan kebijakan untuk membatasi tatap muka pada seluruh sekolah di Indonesia bahkan di dunia. Maka ini menjadi sinyal bagi kita untuk beralih ke arah penggunaan teknologi yang lebih luas untuk memberikan kesinambungan dalam pembelajaran.

Pada masa yang akan datang dapat dilakukan pengembangan terhadap metode pembelajaran Blended Learning menuju ke model pembelajaran Hybrid Learning. Metode pembelajaran Blended Learning sebenarnya hampir sama dengan Blended Learning yaitu melakukan pembelajaran langsung dan pembelajaran jarak jauh ini adalah salah satu dari 
banyak model yang diusulkan untuk masa depan pembelajaran dan pendidikan yang dibantu dengan penggunaan teknologi..

Pengembangan Blended Learning dapat dilakukan dengan memperkuat sisi teknologinya, yaitu dengan menggunakan LMS (Learning Management System). Learning Management System atau disingkat LMS menurut Ellis (2009) dalam (Setya, dkk, 2011) adalah suatu perangkat lunak (software) untuk keperluan administrasi, dokumentasi, laporan sebuah kegiatan, kegiatan belajar mengajar dan kegiatan secara online, e-learning dan materi-materi pelatihan, yang semua itu dilakukan dengan online. Lebih lanjut, Riyadi (2010) dalam (Setya, dkk, 2011) menjelaskan bahwa LMS adalah perangkat lunak yang digunakan untuk membuat materi perkuliahan online berbasis web dan mengelola kegiatan pembelajaran serta hasil-hasilnya. Di dalam LMS juga terdapat fitur-fitur yang dapat memenuhi semua kebutuhan pengguna dalam hal pembelajaran. Fitur-fitur tersebut antara lain administrasi, penyampaian materi dan kemudahan akses ke sumber referensi, penilaian, ujian online, pengumpulan feedback serta komunikasi yang mencakup forum diskusi online, mailing list diskusi, dan chating. LMS juga dapat membantu dalam merencanakan, mengimplementasikan, dan menilai sebuah proses pembelajaran. Melalui LMS ini guru tidak hanya dapat memberikan berbagai sumber ajar kepada siswa, tetapi ia juga dapat meminta siswa mengumpulkan (meng-upload) tugas, menilai tugas siswa, memberikan feedback secara langsung, memantau keaktifan siswa, berdiskusi, melakukan video conferences, melakukan evaluasi, bahkan melakukan refleksi pembelajaran. Sebenarnya masih banyak lagi hal-hal yang dapat dilakukan melalui LMS ini. Salah satu LMS yang dapat digunakan untuk pembelajaran adalah Moodle.

Moodle adalah sebuah platform untuk belajar (learning platform) yang didesain khusus bagi pendidik, admin dan siswa-siswanya. Moodle sebenarnya merupakan singkatan dari Modular Object Oriented Dynamic Learning Environment. Platform ini tergolong CMS (Conten Management System) namun khusus bagi kepentingan edukasi. CMS yang satu ini dirancang sedemikian rupa dengan sistem yang kuat, aman dan terintegrasi.

Moodle (Modular Object Oriented Dynamic Learning Environment) adalah software yang merupakan salah satu aplikasi dari konsep dan mekanisme belajar mengajar yang memanfaatkan teknologi informasi, yang dikenal dengan konsep e-learning. Moodle dapat digunakan secara bebas sebagai produk sumber terbuka (open source) di bawah lisensi General Public License dan dapat didownload secara gratis dari www.moodle.org. Aplikasi Moodle dikembangkan pertama kali oleh Martin Dougiamas pada Agustus 2002 
dengan Moodle Versi 1.0 dan merupakan program open source yang paling terkenal di antara program-program e-learning yang ada (Amiroh, 2012) dalam (Sugiarti, 2017).

Evan Johan, dkk (2020) menjelaskan bahwa dalam aplikasi Moodle terdapat beberapa komponen dengan fungsi yang berbeda-beda yang dapat mendukung proses pembelajaran. Komponen-komponen tersebut meliputi Activities (Aktivitas), Search Forum (Pencarian Forum), Administration (Administrasi) dan Course Categories (Kategori Pelajaran). Setiap komponen moodle memiliki fungsi yang berbeda-beda untuk mengembangkan moodle sesuai dengan pengguna inginkan.

Rulianto (2009), mengungkapkan bahwa platform Moodle ini memiliki beberapa kelebihan dibandingkan dengan platform lain. Kelebihan tersebut diantaranya adalah sebagai berikut.

1. Moodle cocok untuk diterapkan dalam kelas online. Selama kelas online bisa memberikan pembelajaran di perangkat moodle yang dapat diakses oleh siapa saja. Bahkan Platform ini dapat diakses lebih dari 1000 materi pembelajaran, sehingga kelas online lebih efesien dan fleksibel.

2. Keamanan moodle telah terjamin, Hal ini karena moodle dilengkapi fitur keamanan yang dapat melindungi data pribadi pengguna. Bahkan saat siswa mengisi formulir pendaftaran, data diperiksa hingga valid karena moodle telah dilengkapi oleh aplikasi..

3. Moodle menyediakan aneka macam bahasa bagi penggunanya. Setiap pengguna dapat memakai bahasa yang diinginkan. Ada 45 bahasa yang kini tersedia di moodle, pilihlah bahasa sesuai kebutuhan pembelajaran.

4. Moodle bersifat open source software, alias gratis dan mudah diakses oleh siapa saja.

5. Moodle memiliki manajemen pengguna, biasa disebut manajamen kursus, pengubahan kursus, pengurangan, dan penambahan jenis kursus.

6. Menyediakan modul chat bot, modul jurnal, modul kuis, modul survei, workshop, polling serta masih banyak lagi modul lainnya.

7. Perangkat sederhana, kompatibel, ringan dan efesien.

Kemudahan lain yang ditawarkan oleh Moodle adalah materi pembelajaran, bahan diskusi atau soal tes dapat diunggah ke dalam sistem e-learning, untuk dapat diakses secara bersama-sama oleh guru dan siswa. Penyajian materi dalam bentuk file dengan berbagai format seperti PDF, DOC, XLS, PPT dan berbagai bentuk lainnya sudah didukung oleh aplikasi moodle. Bahkan untuk dosen yang memiliki akun pada penyimpanan berbasis Cloud 
seperti misalnya Google Drive, Box, Dropbox dan sebagainya, dapat ditautkan ke aplikasi moodle (Asnurul, 2020).

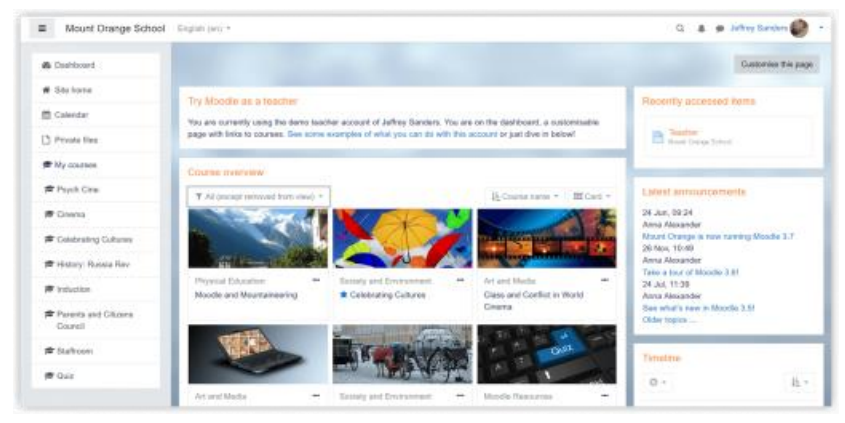

Sumber : http://niagahoster.co,id/blog/moodle

Gambar 4. Halaman Dashdoard Moodle

Aplikasi LMS berbasis Moodle ini sangat mudah digunakan. Arif (2017) menjekaskan, ada dua cara dalam menginstal aplikasi moodle, yaitu instalasi secara daring (online) dan atau instalasi secara luring (offline). Instalasi secara daring (online) adalah instalasi atau pemasangan yang dilakukan dengan terhubung langsung dengan internet. Sementara instalasi secara luring (offline) adalah instalasi atau pemasangan yang dilakukan tanpa terhubung dengan internet. Keduanya memiliki langkah atau prosedur yang berbeda. Pada pengembangan $e$-learning berbasis moodle ini, instalasi atau pemasangan aplikasi dilakukan secara daring (online) dengan menggunakan domain sekolah. Untuk memperoleh domain, sekolah dapat menggunakan layanan jasa hosting dan domain dalam negeri, antara lain: Rumah Hosting, Idwebhost, JagoanHosting, Idhostinger, dan lain-lain (Indah, 2017).

Setelah e-learning berbasis Moodle selesai dan sempurna proses instalasinya maka selanjutnya adalah proses mengatur, mengubah dan membuat perwajahan serta menu-menu yang akan dimunculkan dalam e-learning berbasis Moodle. Setelah seluruh proses instalasi dan pengaturan selesai e-learning berbasis Moodle ini dapat digunakan sebagai media pembelajaran baik pada masa Pandemi Covid-19 ini maupun pada masa yang akan datang.

\section{KESIMPULAN}

Pandemi Covid-19 membuat dunia pendidikan Indonesia berbenah, terutama dalam sarana dan prasarana. Terjadi perubahan pola pembelajaran dari pembelajaran daring ke pembelajaran online sesuai dengan regulasi yang di keluarkan oleh pemerintah. Pemerintah Provinsi Nusa Tenggara Barat melalui Dinas Pendidikan dan Kebudayaan Provinsi Nusa 
Tenggara Barat telah mengeluarkan surat edaran sebagai dasar pelaksanaan pembelajaran jara jauh.

SMAN 1 Maggelewa sebagai salah satu sekolah di bawah naungan Dinas mewujudkan regulasi pemerintah dalam pentuk penyelenggaran pembelajaran model Blended Learning, yaitu kombinasi pembelajaran tatap muka dan pembelajaran yang dilakukan secara daring atau online. Dalam pelaksanaanya pembelajaran daring atau online menggunakan aplikasi WhatsApp sebagai media. Secara teknis, guru mata pelajaran membuat group yang beranggotakan siswa dan dalam grup tersebut guru memberikan materi pembelajaran kemudian siswa merespon. Guru mencatat respon yang diberikan oleh siswa dan di tuangkan dalam laporan pembelajaran online.

Pelaksanaan Blended Learning berbasis WhatsApp di SMAN 1 Manggelewa berjalan baik dan lancar. Salah satu faktor pendukung adalah hampir seluruh guru dan siswa telah memiliki Smartphone dan sudah mahir dalam mengoperasikan aplikasi WhatsApp. Namun demikian bukan berarti Pelaksanaan Blended Learning di SMAN 1 Manggelewa tanpa kendala. Kendala yang ditemui dalam proses pembelajaran online adalah tidak meratanya fasilitas yang dimiliki oleh siswa, ketersediaan jaringan internet dan kurangnya dukungan dari orangtua siswa.

Meski model Blended Learning berbasis WhatsApp telah berjalan pada masa pandemi Covid-19 ini, perlu adanya pengembangan lebih lanjut untuk meningkatkan kualitas pembelajaran. Jika saat ini pembelajaran berbasis aplikasi WhatsApp maka di masa depan dapat meningkat dengan menggunakan LMS (Learning Management System), salah satunya dengan Moodle. Dengan menggunakan LMS (Learning Management System) akan sangat menarik dan sangat membantu proses pembelajaran dari perencanaan hingga evaluasi.

\section{DAFTAR PUSTAKA}

Agus Wilson. (2020). Penerapan Model Pembelajaran Daring (Online) Melalui Aplikasi Berbasis Android Saat Pandemi Global: SAP (Susunan Artikel Pendidikan). 5(1)

Allen Elaine, Jeff Seaman, and Richard Garrett. (2007). Blending In The Extent and Promise of Blended Education in the United States. United States of America: Sloan-C ${ }^{\mathrm{TM}}$

Asnurul Isroqmi. (2010). Pentingnya penguasaan Beberapa Palikasi Komputer Bagi Dosen di Pembelajaran Daring Berbasis Moodle, Prosiding Seminar Nasional Pendidikan Program Pascasarjana Universitas PGRI Palembang, 67(1)

Bahrul Khair Amal. (2019). Pembelajaran Blended Learning Melalui WhatsApp Group (WAG). Prosiding Seminar Nasional Fakultas Ilmu Sosial Universitas Negeri Medan, 700(3). 
Bambang Joko Surya. (2019). Pengaruh Metode Blended Learning Berbasis Web dan Motivasi Terhadap Hasil Belajar Biologi Pada Pokok Bahasan Klasifikasi Makhluk Hidup di Kelas X SMA Negeri Secanggang Langkat: Jurnal Biolokus, 2(1).

Ervan Johan Wicaksana, Pramana Atmadja, Widya Lestari, Luvita Agus Tanti, Ririn Odrina. (2020). Efektifitas Pembelajaran Menggunakan Moodle Terhadap Motivasi dan Minat Bakat Peserta Didik di Tengah Pandemi Covid-19: EduTeach Jurnal Edukasi dan Teknologi Pembelajaran, 1(2).

Fathu Khaerunnisa. (2019). Evaluasi Penerapan Blended Learning Pada Pembelajaran Bahasa Arab di SMPIT Ibadurrahman; Studi Kasus di Kelas VII AKhwat: ALSUNIYAT Jurnal Penelitian Bahasa Arab, Sastra, dan Budaya Arab, 2(2).

Husamah. (2014). Pembelajaran Bauran (Blended Learning). Malang: Prestasi Pustaka Publisher.

Indah Wijaya Antasari. (2017). Membuat Website/Blog Profesional Sebagai Sarana Penyebaran Informasi Sekolah: Media Pustakawan, 24(2).

I Made Pustikayasa. (2019). Group WhatsApp Sebagai Media Pembelajaran (WhatsApp Group As Learning Media): Widya Genitri; Jurnal Ilmiah Pendidikan Agama dan Kebudayaan Hindu, 10(2).

Miksan Ansori. (2018). Desain dan Evaluasi Pembelajaran Blended Learning Berbasis WhatsApp Group (WAG): Jurnal Dirasah, 1(1).

Milya Sari. (2014). Blended Learning, Model Pembelajaran Abad ke-21 di Perguruan Tinggi: Jurnal Ta'dib, 17(2).

Muhammad Wildan Sahidillah dan Prarasto Miftahurrisqi. (2019). WhatsApp Sebagai Media Literasi Digital Siswa: Jurnal Varia Pendidikan, 31(1).

Setya Raharja, Lantip Dian Prasojo dan Ariyawan Agung Nugroho. (2011). Model Pembelajaran Berbasis Learning Management System Dengan Pengembangan Software Moodle di Sekolah Menengah Atas: Jurnal Kependidikan, 41(1).

Sugiarti. (2017). E-Learning Berbasis Moodle Pada Pembelajaran IPA di Sekolah. Mangifera Edu Jurnal Biologi dan Pendidikan Biologi, 2(1).

Sugiyono. (2010). Metode Penelitian Pendidikan Pendekatan Kuantitatif, kualitatif, dan $R \& D$. Bandung: Alfabeta

Siti Istiningsih dan Hasbullah. (2019). Blended Learning, Trend Strategi Pembelajaran Masa Depan. Jurnal Elemen, 1(1).

Walib Abdullah. (2017). Model Blended Learning Dalam Meningkatkan Efektifitas Pembelajaran: FIKROTUNA Jurnal Pendidikan dan Manajemen Pendidikan Islam, 7(1).

Watie E. D. S. (2011). Komunikasi dan Media Sosial (Communication and Social Media): The Messenger, 3(1). 